\title{
Occurrence of scheelite with anomalous content of basemetals in high Ba-bearing amphibolite of Gattihosahalli schist belt, Karnataka - C. Srinivasaiah (Email: csrinivasasaiah@yahoo.com)
}

The purpose of this note is to place on record the first reported occurrence of scheelite together with anomalous content of basemetals and barium in the Mesoarchaean Gattihosahalli schist belt in Western Dharwar craton. In the regional stratigraphy of the craton, the Gattihosahalli schist belt has been classified under Sargur schist complex of Palaeo- to Mesoarchaean age.

Scheelite occurs as disseminated grains in a very narrow band of amphibolite which occurs at the interface between an underlying unit of ultramafic komatiite, komatiitic basalt and an overlying sequence of interbedded green fuchsite quartzite, barites, whitish quartzite and kyanitesillimanite-quartz-sericite schist. This lithological assemblage is intruded by and also co-folded with sheets of gneisses and granites of $>3.0 \mathrm{Ga}$ age.

The amphibolite band is greenish grey, massive, hard, schistose and unusually heavy. It is predominantly composed of tremolite followed by chlorite, celsian $\left(\mathrm{BaAl}_{2} \mathrm{Si}_{2} \mathrm{O}_{8}\right)$, epidote, sphene and grains of barite. Thickness of the amphibolite band varies from $10 \mathrm{~cm}$ to $50 \mathrm{~cm}$ and extends intermittently over a length of $100 \mathrm{~m}$ as traced tentatively by the author in the field.

The scheelite was identified by its flourescent blue colour under UV lamp. It is disseminated in the form of rounded to elongate grains disposed parallel to the schistosity in the amphibolite. The unusually heavy character of the amphibolite prompted the author to get a few samples analysed for all the elements. Five samples (Ghh 3B, 6, 6A, 14 and 16) of the amphibolite were analysed by XRF at the Acme Analytical Laboratories Ltd, Technical University of Clausthal Germany; at NGRI, Hyderabad, by the same XRF method for major and trace elements and at Shiva Analyticals (India) Ltd., Bangalore, by Fusion method followed by ICPOES and ICPMS.

Tungsten is in the range of $39 \mathrm{ppm}$ to $396 \mathrm{ppm}$. In addition, the amphibolite contains anomalously high $\mathrm{Zn}$ with a high of 516 ppm (average being $286 \mathrm{ppm}$ ), $\mathrm{Cu}$ average $46 \mathrm{ppm}$ (with a high of $125 \mathrm{ppm}$ ), strontium average $350 \mathrm{ppm}$ (with a high of 1068 ppm), cobalt average 134 ppm (with a high of $310 \mathrm{ppm}$ ), barium average 2400 ppm (with a high of 9107 ppm). The high barium is due to the presence of celsian and also grains of barite $\left(\mathrm{BaSO}_{4}\right)$ in the amphibolite. The presence of high barium in the depositional environment is supported by the presence of bedded barytes in the early Archaean rocks of Ghattihosahalli belt, attention to which was first drawn by Radhakrishna and Srinivasaiah (1974, JGSI, v.15, pp.314-315). The amphibolite also contains very high chromium (Av. 2847 ppm, with a high of $4058 \mathrm{ppm}$ ) and nickel (Av.1082 ppm, with a high of 2023 ppm).

The other occurrences of scheelite with elevated levels of $\mathrm{Cr}, \mathrm{Ni}, \mathrm{Zn}$ and $\mathrm{Ba}$ of Palaeo to Mesoarchean age known to the author are from the Nuuk area in West Greenland where it occurs in calc-silicate zones in komatiites and in the 3.8 Ga old Isua supracrustal belt at Isukasia, also in West Greenland, where it occurs in banded amphibolites (Appel, P.W.U., 1983, Rapp. Groundlands geol. Unders., v.115, pp.6467). A detailed study is being undertaken. 